Prepared in cooperation with the New York State Department of Environmental Conservation

\title{
Hydrogeologic and Geospatial Data for the Assessment of Focused Recharge to the Carbonate-Rock Aquifer in Genesee County, New York
}

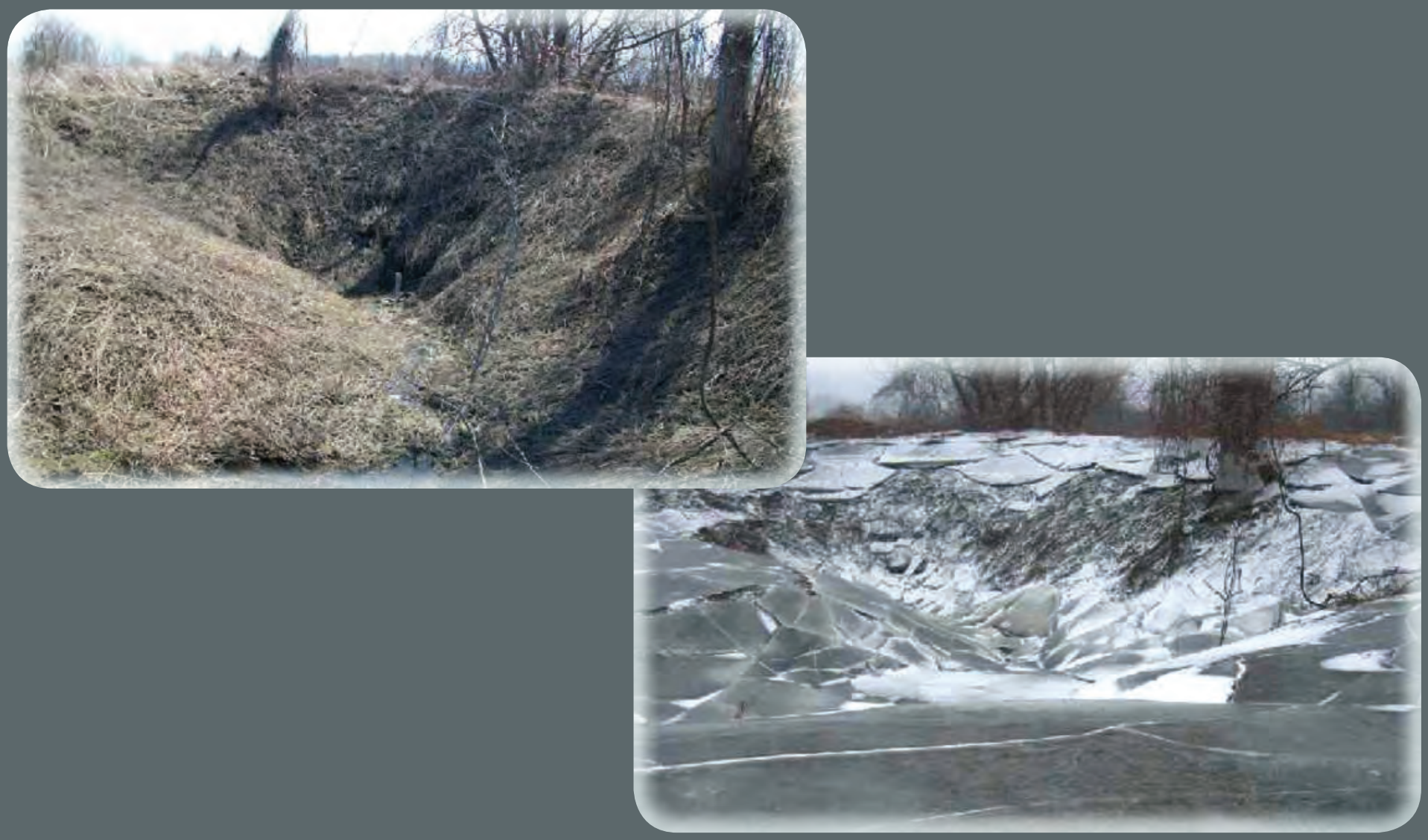

Scientific Investigations Map 3132

U.S. Department of the Interior

U.S. Geological Survey 
Cover. Sinkhole located near Quinlan Road in southeastern Genesee County, New York. Photograph on the left shows water entering the sinkhole during the fall. Photograph on the right shows the same sinkhole in the spring when the water level rose during snowmelt runoff, then froze and was followed by water draining into the sink and the subsequent collapse of the ice sheet. Photographs from Richards, P.L., Libby, Jill, Kuhl, Alex, Daniluk, T.L., and Lyzwa, Mike, 2010, Prediction of areas sensitive to the fertilizer application in thinly-soiled karst-final report: Brockport, NY, State University of New York at Brockport, 27 p. (courtesy of Dr. Richards). 


\section{Hydrogeologic and Geospatial Data for the Assessment of Focused Recharge to the Carbonate-Rock Aquifer in Genesee County, New York}

By James E. Reddy and William M. Kappel

Prepared in cooperation with the

New York State Department of Environmental Conservation

Scientific Investigations Map 3132 


\title{
U.S. Department of the Interior \\ KEN SALAZAR, Secretary
}

\author{
U.S. Geological Survey \\ Suzette M. Kimball, Acting Director
}

U.S. Geological Survey, Reston, Virginia: 2010

For more information on the USGS - the Federal source for science about the Earth, its natural and living resources, natural hazards, and the environment, visit http://www.usgs.gov or call 1-888-ASK-USGS

For an overview of USGS information products, including maps, imagery, and publications, visit http://www.usgs.gov/pubprod

To order this and other USGS information products, visit http://store.usgs.gov

Any use of trade, product, or firm names is for descriptive purposes only and does not imply endorsement by the U.S. Government.

Although this report is in the public domain, permission must be secured from the individual copyright owners to reproduce any copyrighted materials contained within this report.

Suggested citation:

Reddy, J.E., and Kappel, W.M., 2010, Compilation of existing hydrogeologic and geospatial data for the assessment of focused recharge to the carbonate-rock aquifer in Genesee County, New York: U.S. Geological Survey Scientific Investigations Map 3132, 17 p., 20 sheets, at http://pubs.usgs.gov/sim/3132/. 


\section{Contents}

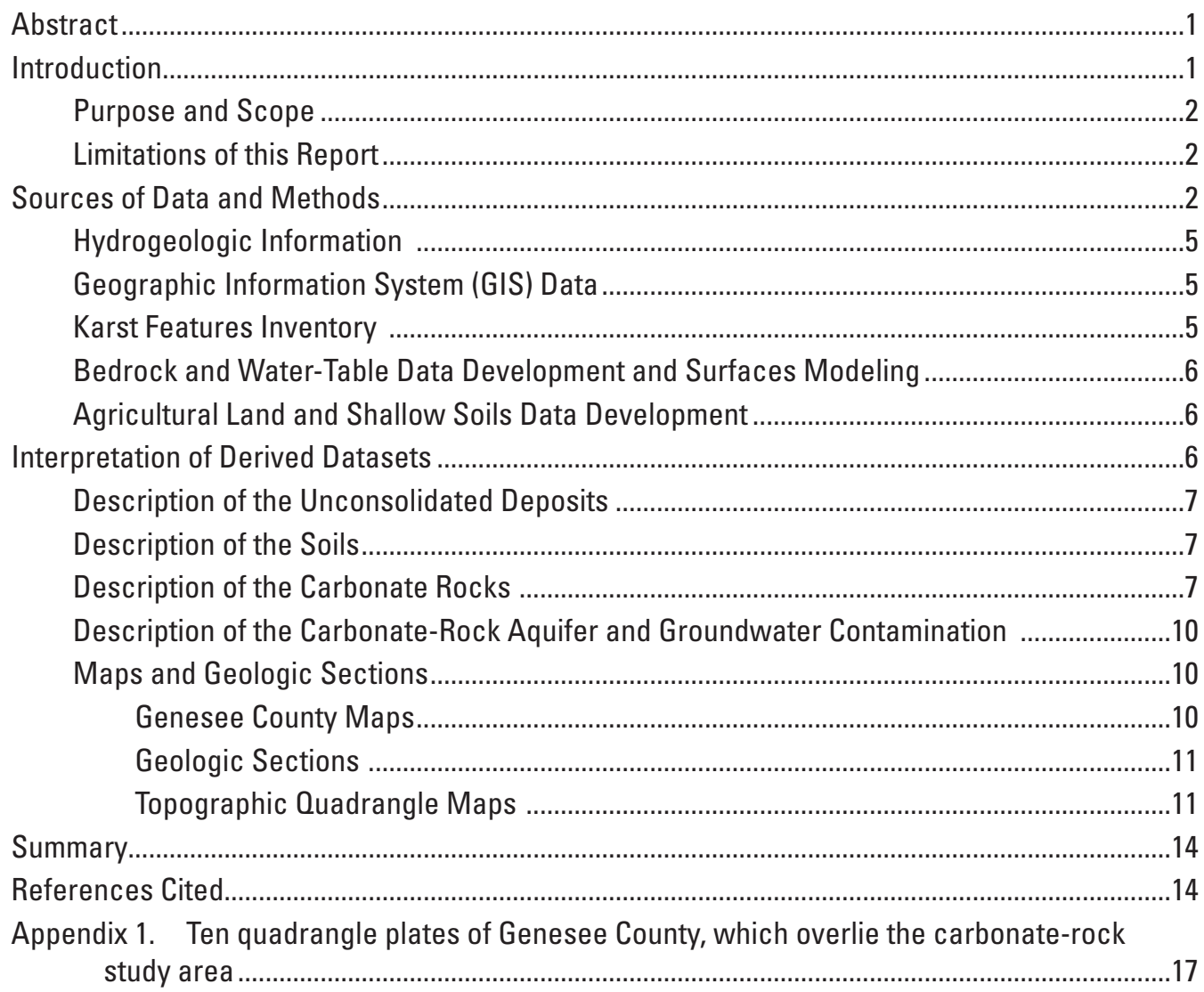

\section{Figures}

1. Map showing location of carbonate-rock study area, wells, karst features, major basins, and smaller subbasins of several karst features that receive surface-water flow in Genesee County, New York

2. Map showing location of carbonate-rock study area, bedrock units, bedrock-surface contours, major faults, and geologic sections in Genesee County, New York.

3. Diagram showing geologic sections $A-A^{\prime}$, east of Batavia; $B-B^{\prime}$, west of Batavia; C-C', west side of Genesee County parallel to State Route 77; and D-D', roughly parallel to the New York State Thruway, Genesee County, New York.

4. Map showing location of carbonate-rock study area, mines, quarries, and gravel pits, generalized water-table contours, and thickness of overburden deposits in Genesee County, New York

5. Map showing location, name, and plate number of the ten 7.5-minute topographic quadrangles that encompass the carbonate-rock study area in Genesee County, New York 


\section{Conversion Factors, Datum, and Acronyms}

\begin{tabular}{|c|c|c|}
\hline Multiply & By & To obtain \\
\hline \multicolumn{3}{|c|}{ Length } \\
\hline inch (in.) & 2.54 & centimeter $(\mathrm{cm})$ \\
\hline foot $(\mathrm{ft})$ & 0.3048 & meter $(\mathrm{m})$ \\
\hline mile (mi) & 1.609 & kilometer $(\mathrm{km})$ \\
\hline \multicolumn{3}{|c|}{ Area } \\
\hline acre & 0.4047 & hectare (ha) \\
\hline inch per hour (in/h) & 0.0254 & meter per hour $(\mathrm{m} / \mathrm{h})$ \\
\hline
\end{tabular}

Vertical coordinate information is referenced to the North American Vertical Datum of 1988 (NAVD 88) on figures $1,2,4$, and 5.

Vertical coordinate information is referenced to the National Geodetic Vertical Datum of 1929 (NGVD 29) on figure 3.

Horizontal coordinate information is referenced to the North American Datum of 1983 (NAD 83).

Altitude, as used in this report, refers to distance above the vertical datum.

\section{List of Acronyms}

$\begin{array}{ll}\text { CLFC } & \text { Clarendon-Linden Fault Complex } \\ \text { DEM } & \text { Digital Elevation Models } \\ \text { GWSI } & \text { Ground Water Site Inventory } \\ \text { IDW } & \text { Inverse distance weighting } \\ \text { LiDAR } & \text { Light Detection And Ranging } \\ \text { NED } & \text { National Elevation Dataset } \\ \text { NHD } & \text { National Hydrography Dataset } \\ \text { NLCD } & \text { National Land Cover Data } \\ \text { NRCS } & \text { Natural Resources Conservation Service } \\ \text { NYSDEC } & \text { New York State Department of Environmental Conservation } \\ \text { NYSDOH } & \text { New York State Department of Health } \\ \text { NYSDOT } & \text { New York State Department of Transportation } \\ \text { SSURGO } & \text { Soil Survey Geographic } \\ \text { SWCD } & \text { Soil-Water Conservation District } \\ \text { SUNY } & \text { State University of New York } \\ \text { TCE } & \text { Trichloroethylene } \\ \text { USDA } & \text { U.S. Department of Agriculture } \\ \text { USEPA } & \text { U.S. Environmental Protection Agency } \\ \text { USGS } & \text { U.S. Geological Survey }\end{array}$




\title{
Hydrogeologic and Geospatial Data for the Assessment of Focused Recharge to the Carbonate-Rock Aquifer in Genesee County, New York
}

\author{
By James E. Reddy and William M. Kappel
}

\section{Abstract}

Existing hydrogeologic and geospatial data useful for the assessment of focused recharge to the carbonate-rock aquifer in the central part of Genesee County, NY, were compiled from numerous local, State, and Federal agency sources. Data sources utilized in this pilot study include available geospatial datasets from Federal and State agencies, interviews with local highway departments and the Genesee County Soil and Water Conservation District, and an initial assessment of karst features through the analysis of ortho-photographs, with minimal field verification. The compiled information is presented in a series of county-wide and quadrangle maps. The county-wide maps present generalized hydrogeologic conditions including distribution of geologic units, major faults, and karst features, and bedrock-surface and water-table configurations. Ten sets of quadrangle maps of the area that overlies the carbonate-rock aquifer present more detailed and additional information including distribution of bedrock outcrops, thin and (or) permeable soils, and karst features such as sinkholes and swallets. Water-resource managers can utilize the information summarized in this report as a guide to their assessment of focused recharge to, and the potential for surface contaminants to reach the carbonate-rock aquifer.

\section{Introduction}

The New York State Department of Environmental Conservation (NYSDEC), New York State Department of Health (NYSDOH) and the Genesee County Health Department have become increasingly concerned about chemical and bacteriological contamination in carbonaterock aquifers. Fecal coliform bacteria, including Escherichia coli (E. coli), and nitrate contamination of groundwater from surface application of liquid manure has occurred several times over the past few years in Genesee County — most recently in early spring of 2010. Nitrate is soluble in water and as such can move readily through thin or permeable soils and enter a carbonate-rock aquifer. Because of their small size, E. coli bacteria can move readily through large pore openings in soil and solution-widened fractures in carbonate bedrock. The watery nature of liquid manure enhances movement of contaminants associated with the manure, especially when surface water mixes with the manure and flows into the carbonate bedrock. Carbonate-rock aquifers in western and central New York also have been contaminated by septic waste and improper chemical disposal and spills, such as the trichloroethylene (TCE) spill in eastern Genesee County (USEPA-http://www.epa.gov/region02/superfund/ npl/0203481c.pdf, accessed March 2009).

Relatively large amounts of recharge can rapidly enter carbonate-rock aquifers as focused recharge where the overlying soils are thin or permeable (sand and gravel) and where some karst features such as swallets (sinkholes that have water flowing into them) receive large amounts of surface water that enter the groundwater system. Where carbonate rocks crop out at or close to land surface, they are typically highly weathered, which allows precipitation and runoff to readily enter the bedrock aquifer. Where the aquifer is karstic, this flow is similar to flow in a pipe. Once contaminants enter the carbonate-rock aquifers in these areas of focused recharge, they can be transported by the groundwater for long distances and affect large parts of the aquifer. The groundwater contamination will persist in a downgradient direction after the source has been removed. If drinking-water wells tap contaminated zones in the aquifer, the groundwater can pose a major and persistent health threat.

Carbonate bedrock is quarried as a mineral resource in numerous locations across the State. Large volumes of groundwater may be pumped locally to dewater quarries to facilitate mining. The dewatering of a quarry can locally lower the water table and may cause nearby water-supply wells to go dry. Additionally, lowering the water table can potentially change the direction of groundwater flow and affect the movement of contaminants in the aquifer. In such cases, water-supply wells either have been deepened or replaced with new wells drilled to an alternate source of water (Staubitz and Miller, 1987). Lowering the water table can substantially affect the water levels in wells within 1,000 feet of Onondaga Limestone quarries in this region and may have some effect on water levels in wells up to a mile or more away (Staubitz and Miller, 1987). 
In Genesee County, carbonate bedrock of the Onondaga Limestone, Akron Dolostone, and Bertie Formation (for simplicity, the last two carbonate units are titled the AkronBertie Formation in this report) crops out along a 2- to 5-mile wide band that trends east-west through the middle of the county (fig. 1). This bedrock sequence is about 180 feet thick and dips gently to the south at about 40 to 50 feet per mile. These units form an extensive and high-yielding carbonaterock aquifer that transmits water through solution-enlarged fractures, bedding planes, and other openings (Olcott, 1995). Furthermore, the Akron-Bertie Formation is stratigraphically below, and crops out north of, the Onondaga Formation and contains thin seams of gypsum (3-to-5 feet thick) that were mined in the past. The abandoned mines contain mineralized water that is sometimes used for industrial purposes such as cooling water. Abandoned mines also are reportedly used to dispose of surface-water runoff (for example, from parking lots) or for dewatering of a locally high water table in an overlying aquifer. These activities can affect the quality and quantity of water in the carbonate-rock aquifer.

Hydrogeologic information on the carbonate-rock aquifer is needed for the management and protection of this important groundwater resource in Genesee County and elsewhere across New York State. The NYSDEC and other State and local agencies, and educational organizations need information in an easy-to-use, accessible product for planning purposes. To meet this need, the U.S. Geological Survey (USGS), in cooperation with the NYSDEC, conducted a study to determine the location of focused recharge, primarily related to karst features in the bedrock. This pilot study was conducted in Genesee County, NY, where carbonate bedrock is found at or near the land surface (fig. 2). One of the first steps in understanding this resource is to determine the character and extent of the carbonate bedrock and compile information on the geology and hydrology of carbonate-rock aquifers where recharge is focused and has the highest potential for rapidly entering the aquifer system. Areas where the carbonate bedrock is at the surface or covered only by thin, permeable soils, and karst settings with sinkholes, swallets, and solution channels and cavities are likely areas of focused, high-volume and rapid recharge and need to be identified to protect the carbonate-rock aquifer.

\section{Purpose and Scope}

This report (1) describes the general characteristics of the carbonate-bedrock aquifer and overlying soils and unconsolidated deposits and (2) presents geospatial information on factors that affect where focused recharge and surface contaminants have the highest potential to enter the carbonate-rock aquifer. The field- and office-based methods used to compile and interpret the data and create the maps in this study are evaluated to improve similar studies in the future.

County-wide maps in this report display hydrogeologic data and include generalized conditions including well locations, bedrock-surface configuration, location of streams, water-table configuration, and location of interpreted bedrock faults. Individual quadrangle maps provided with the report display more-detailed hydrogeologic, soils, and karst information in areas that overlie the carbonate-rock aquifer in Genesee County. Also included are four geologic sections that depict sectional views of soil and bedrock characteristics, including location of water-bearing zones in the carbonate bedrock

\section{Limitations of this Report}

Although the information in this report can be used for planning purposes, it is not a substitute for site-specific hydrogeologic investigation. The presence of any karst feature - a sinkhole, a surface depression, or a losing or gaining stream channel-depends on numerous factors including - (1) the bedrock type, (2) bedrock geologic structure (fractures, joints, faults), (3) the surface and subsurface hydrology (preferential-flow pathways formed by the dissolution of the carbonate bedrock along existing geologic structures), (4) thickness and permeability of soils overlying the carbonate bedrock, and (5) land use (urbanized, farmed, or unused). Urbanization can mask the surface expression of karst features when the land surface is modified. Though reports of such features will be recorded when they become apparent in populated areas, similar features on a farm or rural land may only be known by the person(s) familiar with that particular area. (The information provided in this paragraph was adapted from the Pennsylvania Department of Conservation and Natural Resources, Map 68-Density of Mapped Karst Features in South-Central and Southeastern Pennsylvania (accessed February 2009 at, http://www.denr. state.pa.us/topogeo/map68/map68txt.aspx.)

\section{Sources of Data and Methods}

This pilot study was designed to utilize existing data from multiple sources to compile information on hydrogeology, soils, and land use overlying the carbonate-rock aquifer and to display this information in a visual form for use by land- and water-resource managers. The data sources include local, State and Federal agencies, and several water-resource studies for Genesee County. 

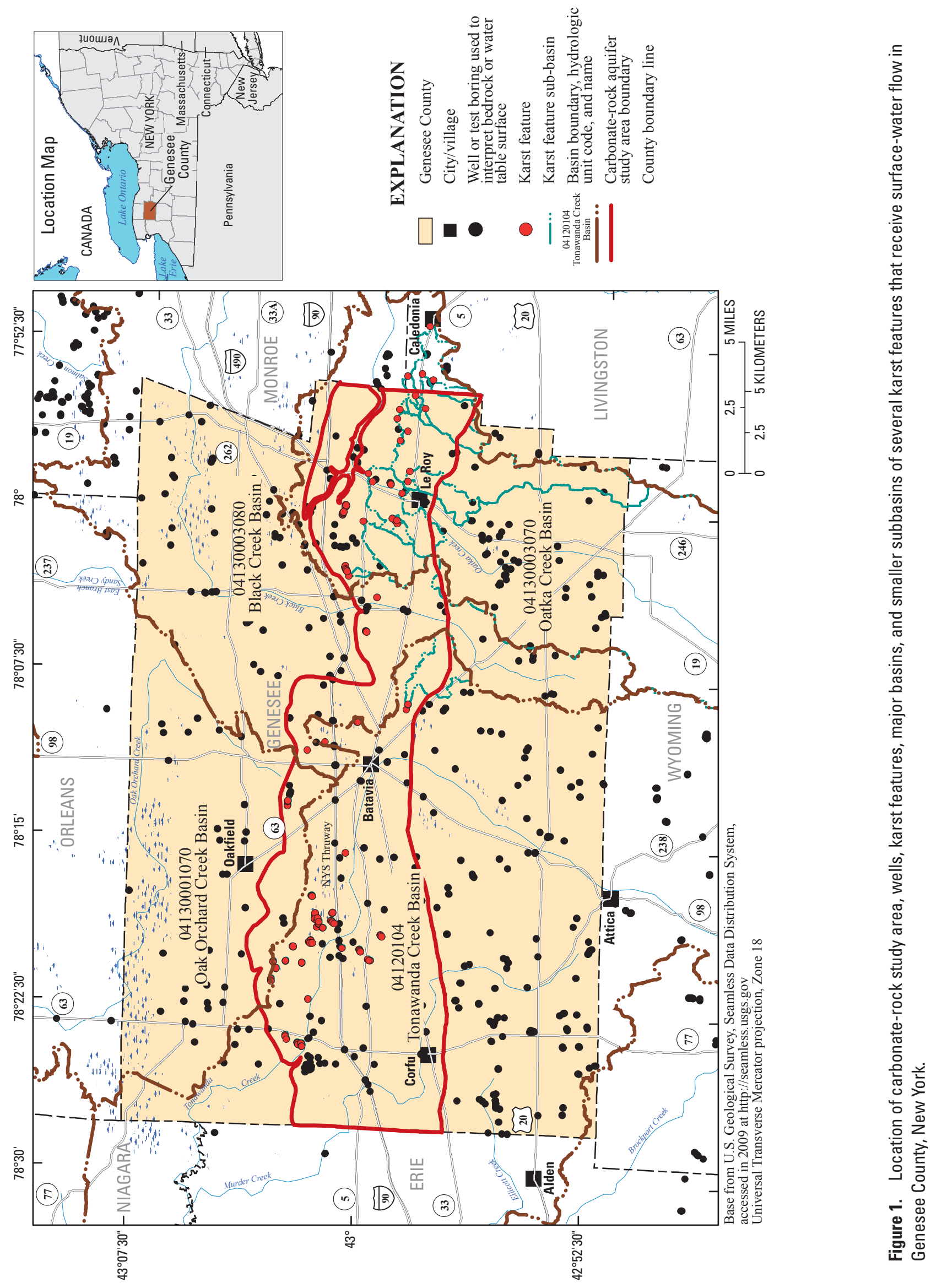


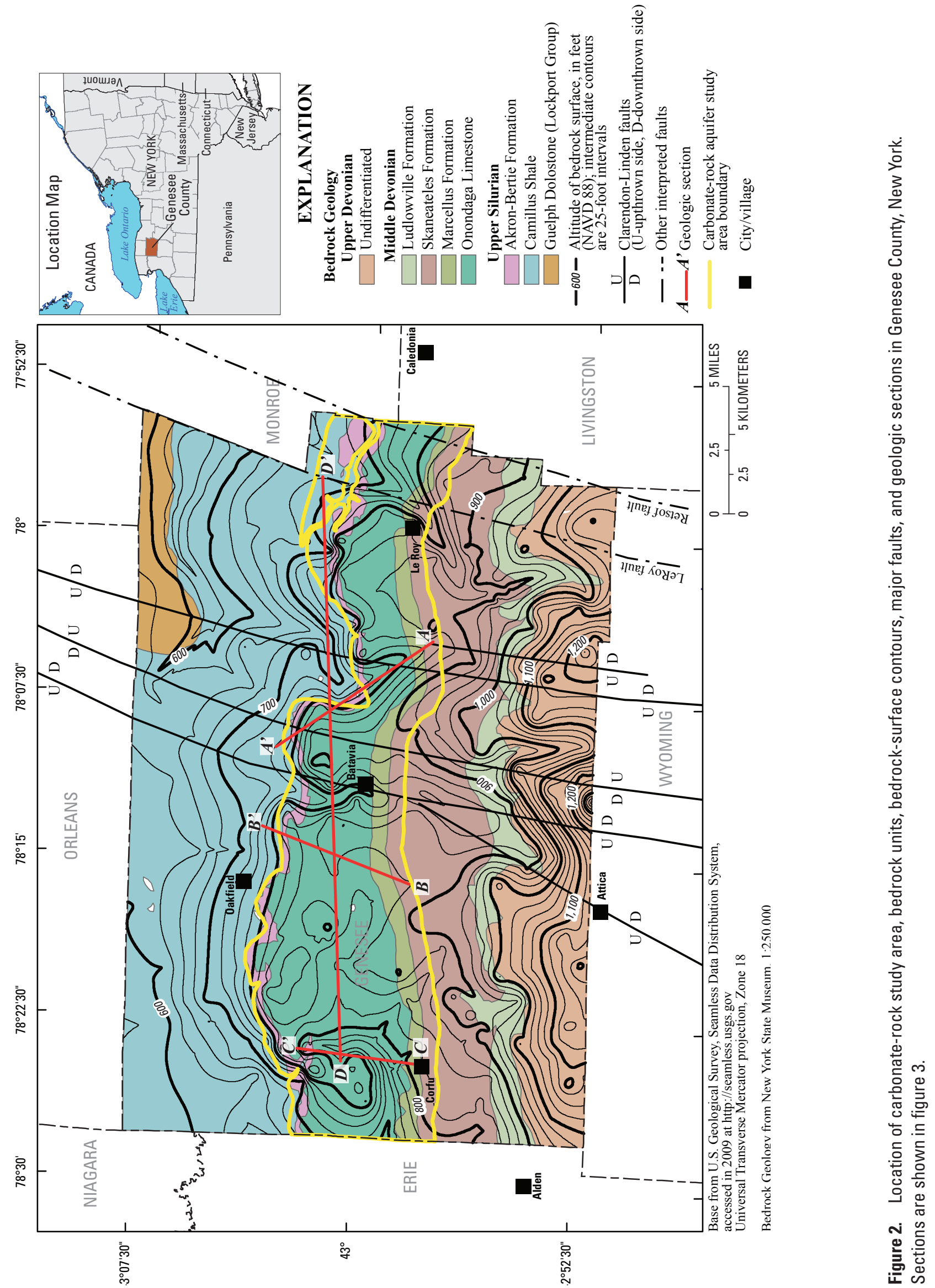




\section{Hydrogeologic Information}

Water-well information was provided through the NYSDEC Water Well Reporting Program (2000-2008) and the USGS Ground Water Site Inventory (GWSI) databases. Only a limited amount of field work was performed for this study to confirm that well locations stored in the NYSDEC Water Well Reporting Program database were correct. Foundationboring logs were obtained from the files of the New York State Department of Transportation (NYSDOT) and the New York State Thruway Authority for roadway and bridge construction sites (1950s-2008). Additional geologic logs were obtained from the files of the NYSDEC Divisions of Water, Hazardous Waste, and Mineral Resources. Other hydrogeologic data were obtained from a literature review of water-resource reports for Genesee County.

\section{Geographic Information System (GIS) Data}

One of the objectives of this study was to develop procedures for GIS assessment of diverse data sets in order to characterize the carbonate-rock aquifer in regard to focused recharge of surface water to the groundwater system. ESRI ArcMap 9.3.1 GIS software (Environmental Systems Research Institute, 2009) was used throughout this pilot study. The following geospatial data were identified as relevant to the study and were acquired for use in this analysis:

- Orthoimage map data (geometrically corrected aerial photographs)

- Land-surface data from the USGS National Elevation Dataset (NED)

- Surface-water data from the USGS National Hydrography Dataset (NHD)

- Land-cover data from the 2001 National Land Cover Data (NLCD)

- Soil-map data from the U.S. Department of Agriculture (USDA), Soil Survey Geographic (SSURGO) Database

- Mine, quarry, and other anthropogenic data from:

- NYSDEC Mining Database

- Dr. Paul Richards and students from the Department of Earth Sciences, State University of New York (SUNY) at Brockport (Richards and others, 2010)

○ Jim Craft-NYSDEC, Avon, NY

- Well and borehole data from:

- NYSDEC Water Well Reporting Program

- USGS Ground Water Site Inventory (GWSI) database
○ NYS Department of Transportation (NYSDOT)

$\circ$ NYS Thruway Authority

- Locations for known spills and other environmental events from:

$\circ$ Genesee County, Department of Health

$\circ$ NYSDOH

- NYSDEC Environmental Remediation Sites database

- Locations of known karst features from:

- Survey responses from the Genesee County SoilWater Conservation District (SWCD) and the Highway Departments from the Towns of Batavia, Elba, Le Roy, and Stafford

- Dr. Paul Richards, Department of Earth Sciences, SUNY at Brockport (Richards and others, 2010)

\section{Karst Features Inventory}

USGS personnel met with representatives of the Genesee County SWCD and Genesee County and town highway departments that were within and adjacent to the carbonaterock study area to solicit the assistance of these stakeholders in creating an inventory of known karst features. Representatives were provided with ortho-photographs of their respective jurisdiction, and a karst feature key was provided to aid in the identification of these features. The participants were asked to record their findings on the maps and return them to USGS for further processing. The Genesee County SWCD and the highway departments from the towns of Batavia, Elba, Le Roy, and Stafford participated in the survey, and their findings were converted to a GIS-compatible format.

These karst features were supplemented with a GIS coverage provided by Dr. Paul Richards, Department of Earth Sciences, SUNY at Brockport, NY (Richards and others, 2010). Dr. Richards and students had identified karst features as part of a study aimed at identifying areas sensitive to fertilizer application in thin soil and karst terrain (Richards and others, 2010). They initially used topographic maps and 10-meter Digital Elevation Models (DEMs) to locate depressions in the land surface; the depressions were later field verified to determine whether each feature was actually a karst feature. LiDAR (Light Detection And Ranging) data, which would have enhanced the inventory process and might have made field verification more efficient, were not available for Genesee County. The available karst data are represented by the karst "point features" identified within the carbonaterock study area. Bedrock outcrops, identified in the SSURGO database, were included with the karst feature dataset because they too represent potential preferential pathways into the carbonate-rock aquifer. 
The USGS StreamStats GIS application (Reis and others, 2008) was used to delineate drainage basins of streams associated with karst features. In cases where the StreamStatsderived basin for a karst feature was negligible, such as those associated with SSURGO-identified bedrock outcrops, ArcGIS was used to assign an arbitrary 500 -foot-radius buffer zone around the feature in lieu of a drainage basin. The ArcGIS Spatial Analyst extension was used to convert the drainage basins and buffer zones to a 10-meter-resolution raster (a cell or area represented by one value) dataset for ease of analysis.

\section{Bedrock and Water-Table Data Development and Surfaces Modeling}

Raster and vector (a polygon, line, or point representing a particular feature) geospatial datasets representing bedrock surface and water table were created for this study. A number of different altitude data sources were used to model these surfaces. Values for depth to bedrock and the water table were primarily estimated from well completion reports submitted by drillers to the NYSDEC Water Well Reporting Program. Other sources of bedrock thickness and depth to the water table were borehole data obtained from the NYSDOT and the NYS Thruway Authority, bedrock outcrop data from the USDA SSURGO database, and well data from the USGS Groundwater Site Inventory (GWSI) database. Combined data from these various sources produced a depth to bedrock dataset consisting of 1,180 points and a depth to the watertable dataset consisting of 390 points. These data points are distributed throughout Genesee County and extend into the neighboring counties of Niagara, Orleans, Monroe, Livingston, Wyoming, and Erie to negate map "edge effects."

Land-surface-altitude data from the NED were obtained for the purpose of estimating bedrock surface and water table for this study. NED land-surface DEM data in resolutions of 1 arc-second (about 30 meters) and 1/3 arc-second (about 10 meters) were acquired. The ArcGIS Spatial Analyst extension was used to assign DEM land-surface altitudes to each of the points in the bedrock and water-table datasets. Bedrock-surface and water-table altitudes were calculated for each of the data points by subtracting their respective depth values from the DEM land-surface altitudes.

Three surface-interpolation methods were attempted for this study - inverse distance weighting (IDW), spline, and kriging. Surface-interpolation is the creation of a continuous surface from measured point locations. IDW and spline are deterministic methods that create surfaces from measured points using an established mathematical model. Kriging also uses a mathematical model but differs from the IDW and spline methods in that it also incorporates a statistical model when creating a surface. Kriging, therefore, yields not only a surface, but a measure of the accuracy of the surface. Of the three surface-interpolation methods attempted, the kriging tools within the ArcGIS Geostatistical Analyst extension yielded the best results. The surface-prediction outputs from this exercise were stored as both raster (ESRI GRID) and vector (contour) datasets.

An overburden thickness dataset was created by subtracting the bedrock-surface raster from the land-surface DEM. Initially, the 10-meter resolution NED land-surface DEM was used, but the resulting overburden grid and contours were misleadingly detailed when compared to the number and distribution of bedrock-surface data points. A less complex result was achieved by using the lower-resolution 30-meter NED land-surface DEM.

\section{Agricultural Land and Shallow Soils Data Development}

Agricultural activity is one of the key land-use factors to consider when assessing the vulnerability of karst areas to groundwater contamination. The 2001 National Land Cover Data (NLCD) dataset was used to identify areas in the carbonate-rock study area where various agricultural activities are likely to occur. The ArcGIS Spatial Analyst extension was used to derive a 10-meter resolution raster dataset comprised of areas with an NLCD land-cover classification of pasture, hay, or cultivated crops.

The presence of shallow soils is another critical consideration when identifying karst-sensitive areas. The USDA SSURGO database represents the best source of large-scale, comprehensive soils data available. SSURGO data for Genesee County and the neighboring counties were acquired. On the basis of a review of the data, 12 soil types were identified as "shallow-to-bedrock" (0-40 inches of soil) for the purposes of this study. The soil types are Allis, Angola, Aurora, Benson, Honeoye, Hornell, Kanona, Lima, Manlius, Newstead, Palatine, and Wassaic.

Initially, only those soils assigned as shallow-to-bedrock with moderate to high infiltration rates were considered in this study. Within the SSURGO database, infiltration rates are represented by the Hydrologic Group classification. Therefore, the initial selection consisted of shallow soils with a hydrologic group classification of "A" (high infiltration rates) or "B" (moderate infiltration rates). Four additional shallow-to-bedrock soil types were added-Aurora, Benson, Wassaic, and Rubbleland soils - after discussions with researchers at Cornell University (Czymmek and others, 2004). These additional soils have been associated with previous groundwater contamination problems in Genesee County, even though these soils have a low infiltration rate. ArcGIS Spatial Analyst extension was used to derive a 10-meter-resolution raster dataset that met the aforementioned soil classification criteria

\section{Interpretation of Derived Datasets}

Analysis of multiple, existing GIS datasets (thematic data layers) provided substantial information to begin 
characterization of the carbonate-rock aquifer in Genesee County. The integration of selected data layers then helped to focus the study on that information that would be most useful in the assessment of focused recharge areas to the carbonaterock aquifer. Interpretations of focused recharge were made using seven thematic data layers: (1) land surface altitude, (2) surface water, (3) land cover, (4) soils, (5) anthropogenic features - mines, quarries, contamination sites, (6) well and borehole data, and (7) karst features were used in the formulation of the study area maps

\section{Description of the Unconsolidated Deposits}

The type and thickness of unconsolidated deposits (soil) found in the study area is the result of multiple glaciations, with the first beginning about 2.6 million years ago and the last ending about 12,000 years ago (Fullerton, 1980). Each period of glaciation effectively obliterated most of the previously deposited sediments; therefore, presentday sediments were deposited during and after the last glacial episode, the late Wisconsinan glaciation. The glacial sediments in the study area consist mostly of unstratified deposits (till) and stratified deposits - glaciolacustrine (lake) and glaciofluvial (stream) sediment. Post-glacial stratified sediments include peat and muck formed in wetlands and alluvium deposited by recent streams. In the study area, till was deposited mostly in the form of drumlin hills and as a thin sheet in the interdrumlin areas. In some places, glaciofluvial sediments consisting mostly of coarse sand and gravel were deposited as hummocky kames (ridges) and possibly as subglacial outwash (fans). As the ice retreated northward across New York, proglacial lakes formed in basins in front of the retreating ice. Stratified fine-grained glaciolacustrine sediments (fine sand, silt, and clay) were deposited mostly in the interdrumlin areas. The soils derived from these glacial and post-glacial deposits are described further on in the report.

\section{Description of the Soils}

The 1969 Genesee County Natural Resources Conservation Service (NRCS) Soil Survey identified 11 soil associations; a soil association is comprised of a general landscape type and one or more major soil types with one or more minor soil types. Eight of the 11 associations were formed from till, while the remaining 3 associations were formed from (1) glaciolacustrine silt and clay, (2) glaciofluvial deposits, and (3) post-glacial muck and peat (Wulforst and others, 1969).

The preponderance of till and glaciolacustrine soils indicates the presence of a variably thick, low-permeability layer of soil over bedrock throughout much of the county. The soils overlying the carbonate bedrock generally have high carbonate content. These soils are derived from the erosion of (1) carbonate bedrock including the Lockport Group that crops out in the northeastern corner of the county, (2) carbonate-rich
Camillus Shale that crops out in the northern part of the county above the Lockport Dolomite, and (3) Bertie-AkronOnondaga carbonate-rock sequence above the Camillus Shale, found along the north side of the study area (fig. 2).

The NRCS soil classification for Genesee County was used to identify 10 soil units that are mapped as "shallow-tobedrock" (0-40 inches of soil over bedrock). While most of these shallow soils have shale parent material, four (Aurora, Benson, Newstead, and Wassaic) are primarily derived from carbonate bedrock, and one shallow soil (Palatine) is derived from calcareous shale. Where these particular "shallow-tobedrock" soils are present, the potential for contaminants to migrate into the carbonate-rock aquifer with focused recharge is greater because of the relatively small soil-water retention and filtering capacity of the shallow soil and the short pathways between the land surface and the groundwater system in the carbonate bedrock. Similarly, consideration of potential interaction between the surface-water and groundwater systems is needed where carbonate bedrock is exposed at land surface near identified karst features, or where surface water flows on, and accumulates over thin soils to a karst feature such as a sinkhole, a swallet, or a losing stream channel. Descriptions of soils, streams, and geologic features are provided on the 10 sets of quadrangle maps for Genesee County (Plates 1 through 10) at the end of the report.

\section{Description of the Carbonate Rocks}

In Genesee County, the Akron-Bertie Formation of Upper Silurian age is overlain by the Onondaga Limestone of Lower Devonian age. The stratigraphic log of a corehole from the Stafford stone quarry, located southeast of Batavia, provides a local example of the bedrock sequence that is common for that part of New York State (fig. 3, line of section A-A'). The Bertie Formation consists mostly of dolomite and dolomitic limestone with interbedded shale, anhydrite, and gypsum seams particularly in the lower part; the formation is about 45 feet thick. The Akron Dolostone is a fine-grained dolomite with a thickness of about 5 feet. The Onondaga Limestone, with a thickness of about 130 feet, forms the upper two-thirds of the carbonate-rock sequence. The Onondaga Limestone consists of three lithologies: a lower coarse-textured, crinoidal limestone that is about 7 feet thick (Edgecliff member); a middle cherty limestone that is about 80 feet thick (Nedrow and Clarence members); and an upper limestone that is about 45 feet thick (Moorehouse and Seneca members). Together the Akron-Bertie Formation through the Onondaga Limestone sequence forms an approximately 180 -foot-thick sequence of carbonate rocks in Genesee County. The Onondaga Limestone is overlain by the Marcellus Shale to the south, and the Camillus Shale is present below the Akron-Bertie Formation carbonate bedrock further to the north. The Onondaga Limestone is resistant to erosion and generally forms an escarpment or cliff-like feature at the land surface along the north side of the study area. The major structural 
South

A

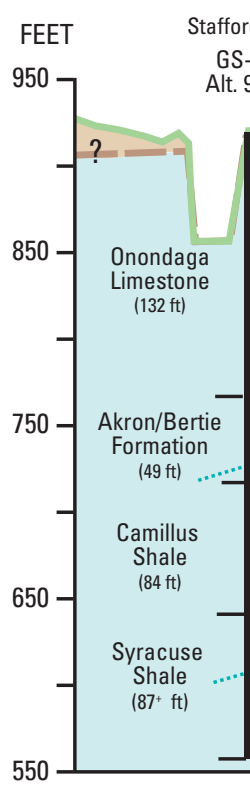

FEET

B

FEET

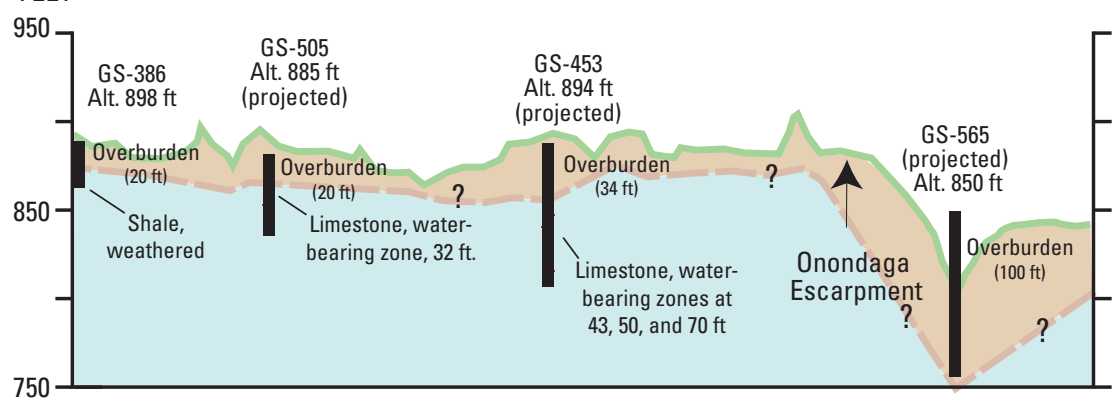

c

FEET

950 NYS Route 77

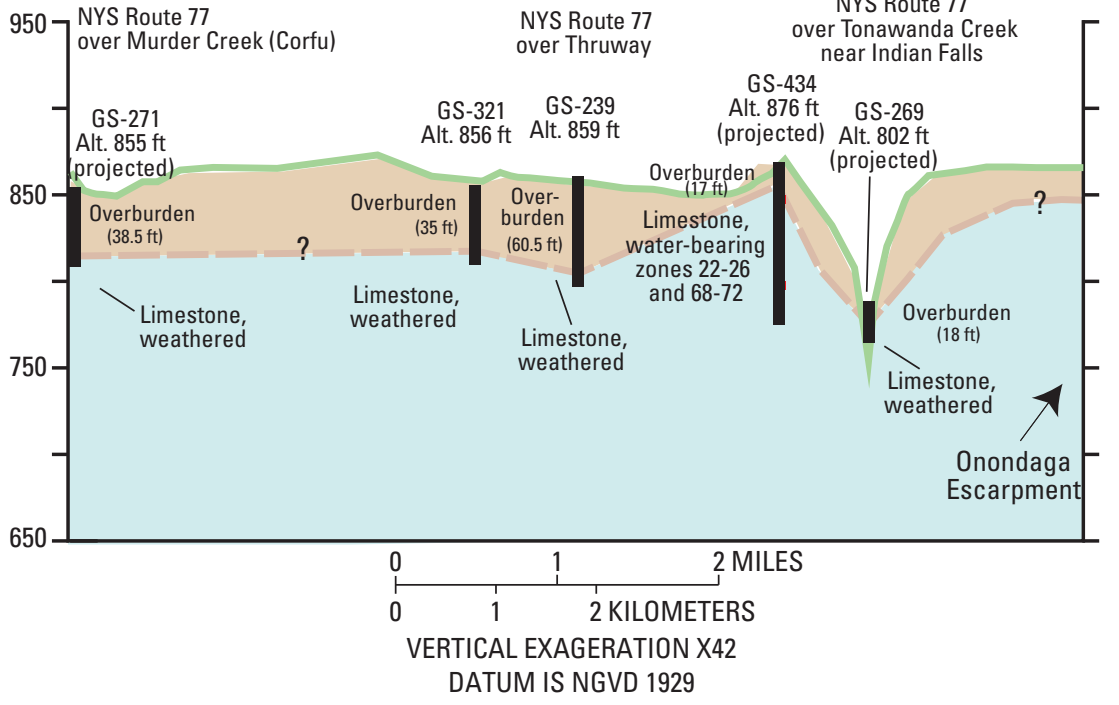
Seneca member $(10 \mathrm{ft})$ NYS Rte 33

GS-217
North

A $^{\prime}$

E. Saile Dr. at Bank St. Batavia Airport NYS-DEC and USGS $920 \mathrm{ft}$

Overburden Moorehouse member ( $36 \mathrm{ft})$ Nedrow member ( $43 \mathrm{ft})$ Clarence member $(36 \mathrm{ft})$ Edgecliff member (7 ft) over Thruway (projected)

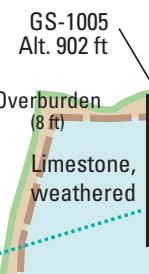
Alt. $905 \mathrm{ft}$
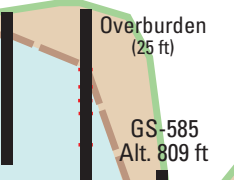

Overburden $(53 \mathrm{ft})$ Limestone,

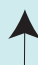

Shaley Average dip of bedrock $\sim 45$ feet per mile to the south
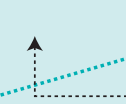

Cl

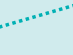

Linden Fault Complex Escarpment

\section{$\Gamma$}

\section{EXPLANATION}

Overburden—glacial clay, silt, sand, and gravel

Bedrock (limestone and shale)—weathered near bedrock surface, competent at depth

Land-surface profile along section

Approximate contact between overburden and bedrock

- Water-bearing zone in bedrock well

Well or test boring - upper number is Genesee County well number assigned by U.S. Geological Survey, and lower number is land-surface altitude at well, in feet (NGVD 1929).

Figure 3. Geologic sections A-A', east of Batavia; $B-B^{\prime}$, west of Batavia; $C-C^{\prime}$, west side of Genesee County parallel to State Route 77; and D-D', roughly parallel to the New York State Thruway, Genesee County, New York. Lines of section are shown in figure 2. 

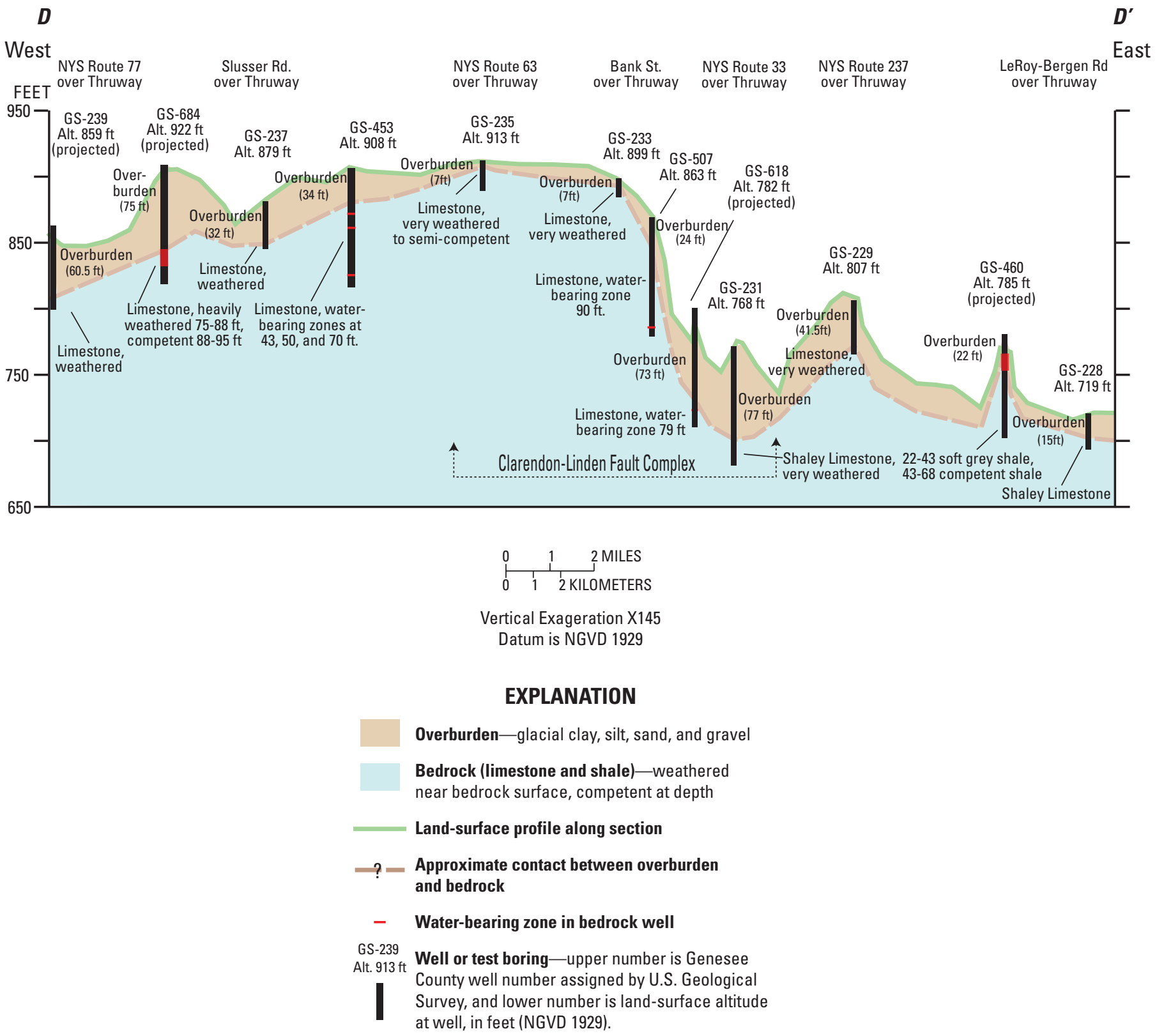

Figure 3. Geologic sections A-A', east of Batavia; $B-B^{\prime}$, west of Batavia; $C-C^{\prime}$, west side of Genesee County parallel to State Route 77; and D-D', roughly parallel to the New York State Thruway, Genesee County, New York. Lines of section are shown in figure 2.-Continued 
feature in this part of New York State is the ClarendonLinden Fault Complex (CLFC), which forms a southwest to northeast series of en echelon faults throughout the bedrock sequence (fig. 2). According to Fakundiny and Pomeroy (2002), the CLFC is a broad zone of small faults with small displacements in the lower Paleozoic bedrock section that is at least $48 \mathrm{mi}(77 \mathrm{~km})$ long and 4.3 to $7.5 \mathrm{mi}(7$ to $17 \mathrm{~km})$ wide and is spatially coincident with a north-trending lineament within the Precambrian basement rock. The relative vertical offset across the fault complex near Attica (southwest of the study area) is more than $300 \mathrm{ft}(91 \mathrm{~m})$ (Fakundiny and Pomeroy, 2002); a smaller, unspecified offset is present near Batavia, NY. Other, smaller faults are located just to the east of the CLFC according to Jacobi (2002). Jacobi identified two north-striking fault systems called the Leroy and Retsof faults based on work done by Rickard (1973) who identified a down-on-the-east offset in bedrock stratigraphy that is based on well logs, Landsat imagery for identifying linear features (EARTHSAT, 1997), and other geologic information collected over the past two decades (Jacobi, 2002, p. 82)

The CLFC is partly responsible for the surface-water drainage pattern in Genesee County. Black and Oatka Creeks (fig. 1) drain to the north and east, whereas Tonawanda and Oak Orchard Creeks drain to the north and west of the CLFC (fig. 1). Groundwater flow patterns also follow this alignment, and the Onondaga Escarpment affects groundwater flow near the escarpment. The Leroy and Retsof faults and any parallel structures between them may have caused the development of "more mature" karst (a well-developed flow system with the carbonate bedrock) in the southeastern part of Genesee County.

\section{Description of the Carbonate-Rock Aquifer and Groundwater Contamination}

The potential for focused recharge to the carbonaterock aquifer is greatest where the rocks crop out at or near land surface and where surface depressions accumulate and focus surface recharge to underlying karst features. Sources of potential recharge include (1) precipitation that falls over the aquifer and infiltrates into fractures in the bedrock; (2) channelized surface runoff that seeps into the bedrock through sinkholes, swallets, and fractures; and (3) runoff derived from adjacent till- or glaciolacustrine-mantled shale uplands (to the south of the Onondaga Limestone, fig. 2), which lose water where flow is northward to the carbonaterock aquifer. Under these conditions, contaminants are of particular concern where focused recharge from the surface can readily infiltrate into the carbonate-rock aquifer.

A number of cases of surface contamination entering the carbonate-rock aquifer over the past two decades in Genesee County indicate an inter-relation between the surfacewater and groundwater systems (Ralph Van Houten, New York State Department of Health, oral commun., 2009, and Nancy Rice, New York State Department of Environmental
Conservation, written commun., 2010). In 1986, a buried residential fuel oil tank was found to be leaking when water from neighboring wells had a petroleum odor and taste. In 1998, at a location nearby to the leaking oil tank, leachate from a field of unharvested and decomposing beets infiltrated the underlying soil and entered the weathered and fractured carbonate bedrock causing a drinking-water well about 100 feet east of the field to become contaminated with beet leachate. In three separate cases, the application of manure to different fields in the Batavia, NY, area resulted in complaints of discolored and foul-smelling water in private water wells. In each case, the manure application was made in late winter, on thin soils over carbonate bedrock. Soon after the manure application, warming temperatures caused the residual snowpack to melt, and in one case, a rain-onsnow event apparently routed manure or manure leachate from the soil surface into the groundwater system. Manure applications during spring 2001 and spring 2007 resulted in the detection of total coliform and E. coli in a number of wells at various distances (hundreds of feet) from each manure application. Differentiation of ruminant (cow) and human coliform species was not performed in these two cases. In the spring 2010 case, advanced coliform testing revealed that the E. coli contamination tested positive for ruminant-specific bacteroridale in water from the three affected wells that were a few hundred feet from the field where the manure was applied. One of the three private water wells and a number of private wells further to the east tested positive for human-specific bacteroridales, unrelated to the manure application. The water that tested positive for human septic waste was suspected to come from individual home septic systems constructed in thin soils over carbonate rock.

\section{Maps and Geologic Sections}

The maps in this report provide an overview of the hydrogeologic conditions across the entire county (well locations, generalized bedrock-surface configuration, location of streams, generalized water-table configuration, and location of CLFC and other nearby fault structures). The 7.5-minute topographic quadrangles provide detailed hydrogeologic information about the carbonate-rock aquifer. The four geologic sections depict sectional views of the soil and carbonate-bedrock characteristics, including the location of water-bearing zones in the carbonate bedrock sequence, as they were noted in the drillers' logs.

\section{Genesee County Maps}

Maps of Genesee County depict the general topography of the bedrock surface and water table, and should be used with caution, especially the water-table contour map. The water-level information reflects water levels in widely dispersed wells completed in unconsolidated and bedrock deposits, and water-level information was collected at 
various times of the year over a period of several decades (1950s-2000s). Therefore, the water-table map represents only a generalized configuration of the regional groundwater table.

Figure 1 presents the location of wells used to obtain water-level measurements, karst features, and basin boundaries for the major streams in Genesee County as well as subbasins that drain to several karst features in the southeastern part of the county where karst development appears to be mature versus the rest of the County. These data points were used in the creation of the generalized bedrock surface (fig. 2) and water-table configuration (fig. 4).

Figure 2 presents the locations of (1) the surficial-bedrock units, (2) the major faults (CLFC and at least two others to the east), and (3) four geologic sections that cross the carbonaterock aquifer. Figure 4 displays the location of (1) mines, bedrock quarries, and large gravel pits, (2) generalized watertable configuration, and (3) generalized overburden thickness.

\section{Geologic Sections}

The thickness of overburden, the bedrock surface, and the location of water-bearing zones in the Onondaga Limestone where indicated on drillers logs, are shown in figures 3A-C, with similar information shown on one east-west geologic section (fig. 3D). In areas where the geologic sections cross the CLFC, there is greater diversity in overburden thickness and where carbonate and shale bedrock horizons are present.

\section{Topographic Quadrangle Maps}

The ten pairs of 7.5 minute topographic maps cover the central part of Genesee County. (The locations of the quadrangles are shown in figure 5.) The maps provide detailed information on areas where the carbonate bedrock is the uppermost bedrock unit, where shale bedrock overlies the carbonate rock within a buffer that is approximately
$7,000 \mathrm{ft}$ wide, and where the shale (Marcellus and Skaneateles Shales) are as much as $50 \mathrm{ft}$ thick south of the carbonate/ shale contact (Map 1 of each set). The buffer area includes additional surface drainage from the shale bedrock that could contribute surface water or groundwater as focused recharge to the carbonate-rock aquifer immediately below the shale or from surface water that might flow north from the shale buffer area onto the carbonate bedrock. See the Batavia South quadrangle (Plate 8, Map 1) in the southeast corner of the study area for an example of a karst-feature subbasin that overlies shale bedrock, drains to the north over carbonate bedrock, and then flows to a point of focused recharge into a swallet feature.

Data depicted on Quadrangle Map 1 of each pair include the surficial bedrock units, location of agricultural landuse areas (cropland, hay, and pasture), location of thin soils over bedrock, and location of documented spill or manure applications, which have compromised local water quality. Also shown are the locations of identified karst features with either a contributing area to a point of focused recharge defined by the StreamStats program (Reis and others, 2008) or an arbitrary $500-\mathrm{ft}$ radius around a karst or bedrock outcrop feature where no clear indication of a stream was found when aerial photographs and topographic maps were reviewed. The explanation box for Map 1 of each pair lists features that appear in the map series. However, not all of the features appear on each Map 1 of a pair.

Data depicted on the Map 2 of each topographic quadrangle pair include the location (1) of wells used to develop the generalized water-table and the bedrock-surface contour maps, (2) anthropogenic features including mines, quarries, gravel pits, that might affect the direction and rate of groundwater flow, (3) agricultural land-use areas (cropland, hay, and pasture), and (4) shallow-to-bedrock soils over bedrock. The explanation box for each Map 2 lists features that appear in the map series. However, not all of the features appear on each Map 2 of a pair. 

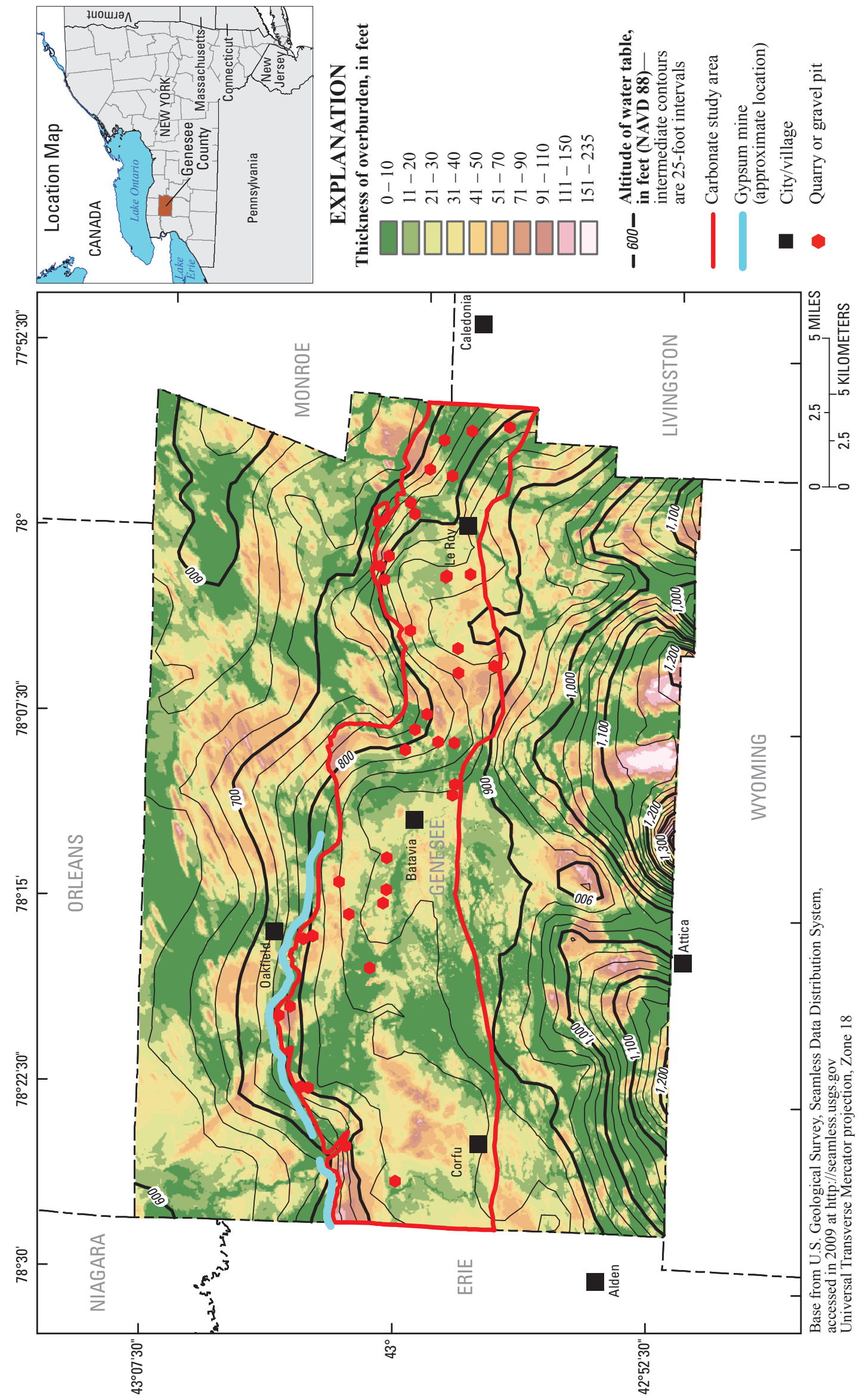

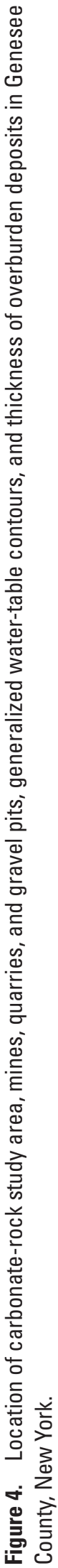




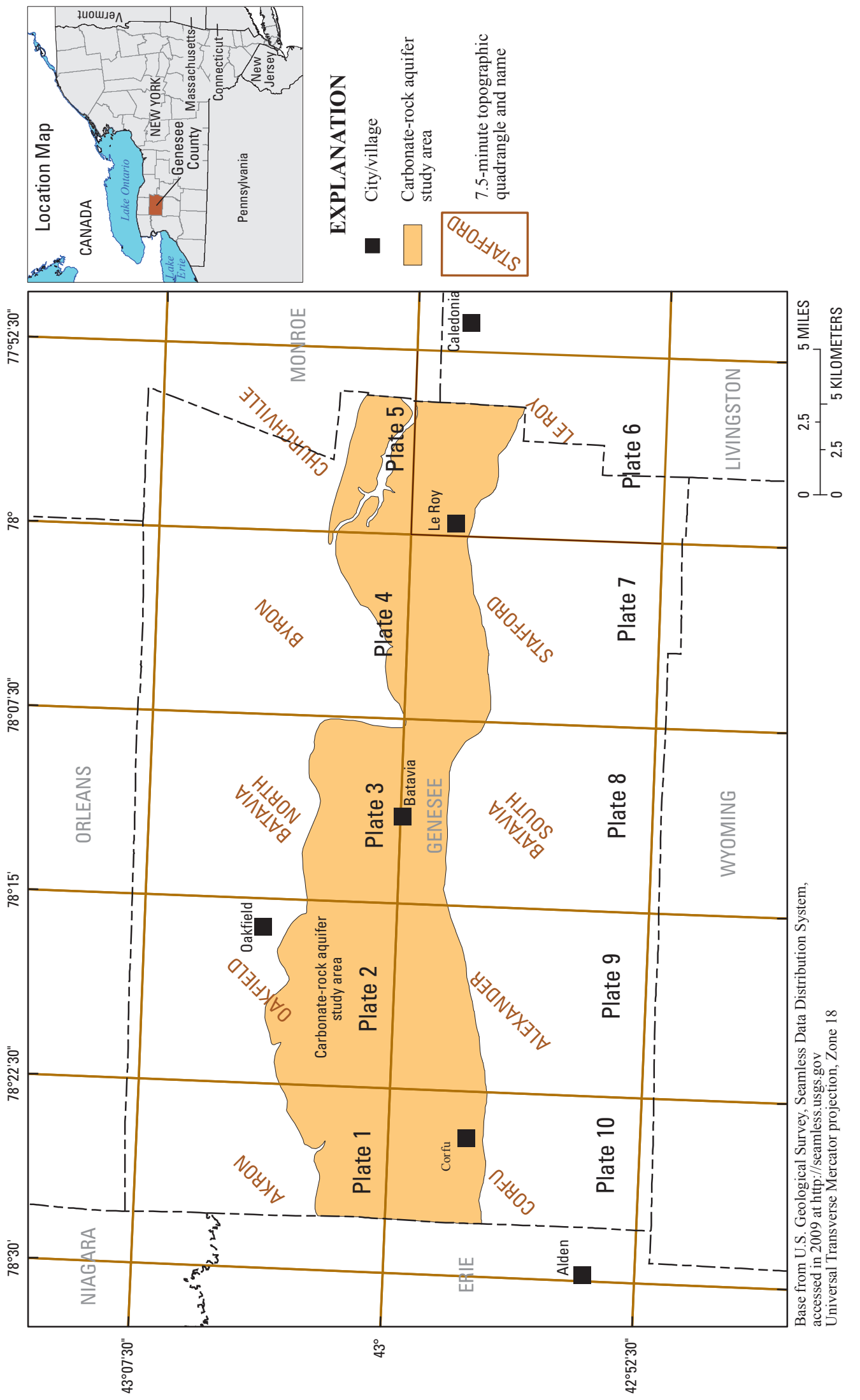

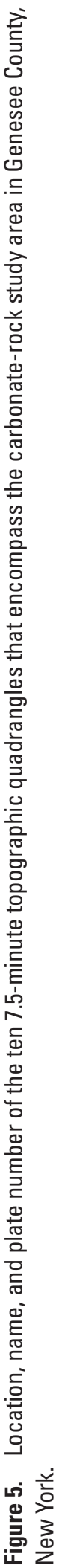




\section{Summary}

Existing hydrogeologic and geospatial data useful for the assessment of focused recharge to the carbonate-rock aquifer in the central part of Genesee County, NY, were compiled from numerous local, State, and Federal agency sources. County-wide maps developed for the study present generalized hydrogeologic conditions including distribution of geologic units, major faults, and karst features, and bedrocksurface and water-table configurations. Quadrangle maps were developed for the area that overlies the carbonate-rock aquifer and present more detailed and additional hydrogeologic information including distribution of bedrock outcrops, thin and (or) permeable soils, and karst features such as sinkholes and swallets.

Water-resource managers can utilize the information summarized in this report as a guide to their assessment of focused recharge in carbonate bedrock and the potential for surface contaminants to reach the carbonate-rock aquifer. Not all karst features were identified in Genesee County because there were limited resources for field verification allotted for this pilot study. As a result, it is assumed that resource managers will make themselves familiar with the area they are assessing, utilize the procedures outlined above to make the best determination regarding the potential vulnerability of a site to an area of focused recharge to the carbonate-rock aquifer and how it might affect the resources being assessed, and then finalize their assessment with field verification. In areas where focused recharge is suspected, site visits by trained personnel are needed to determine the vulnerability of a particular site of focused recharge in relation to an aquifer or an activity or contaminant source of concern.

If additional similar carbonate-rock aquifer studies are conducted elsewhere in New York State, allocating more field time to locate karst features would help enhance and verify the geospatial interpretive processes described above. Verification of water wells identified in the NYSDEC Water Well Reporting Program database is required, and while office verification is possible if tax maps, ortho-photographs, and positional information on the water-well forms coincide, there is a need for actual field verification when these data sources do not agree.

Similarly, the location of karst features cannot be easily discerned in many cases just by review of orthophotographs, topographic maps, or even from the memory of local individuals who might locate karst features on a map. These sources serve as a good first level of analysis, but field verification would provide more definitive location information and hydrogeologic attributes for each particular karst feature.

High resolution, land-surface elevation data, such as LiDAR, would be most useful in helping to enhance identification of karst. Subtle geographic features (inch-to-foot scale resolution) can be identified and would be useful in interpreting the location of karst features, making identification easier and more reliable. LiDAR is not presently available in many counties in upstate New York where carbonate bedrock is present, but where it is available, LiDAR may provide an additional tool and more-precise procedures to characterize surficial expressions of karst features.

\section{References Cited}

Cadwell, D.H., 1988, Surficial Geologic Map of New York -Niagara Sheet: Albany, New York, New York State Museum, Map and Chart Series Number 40, 1 sheet, $1: 250,000$ scale.

Czymmek, Karl, van Es, Harold, and Geohring, Larry, 2004, Manure and groundwater-the case for protective measures and supporting guidelines: Ithaca, NY, Cornell University, Department of Crop and Soil Sciences, and Department of Biological and Environmental Engineering, 10 p.

EARTHSAT, 1997, Remote sensing and fracture analysis for petroleum exploration of Ordovician to Devonian fracture reservoirs in New York State: Albany, NY, New York State Energy Research Development Authority, 35 p.

Environmental Systems Research Institute, 2009, ArcGIS Version 9.3.1: Redlands, California, Environmental Systems Research Institute, unpaginated (available at (http://www.esri.com/software/arcgis/eval-help/index.html).

Fakundiny, R.H., and Pomeroy, P.W., 2002, Seismic-reflection profiles of the central part of the Clarendon-Linden fault system of western New York in relation to regional seismicity: Tectonophysics, v. 353, Issues 1-4, p. 173-213.

Fullerton, D.S., 1980, Preliminary correlation of post-Erie interstadial events $(16,000-10,000$ radiocarbon years before present), central and eastern Great Lakes region, and Hudson, Champlain, and St. Lawrence lowlands, United States and Canada: U.S. Geological Survey Professional Paper 1089, 52 p.

Jacobi, R.D., 2002, Basement faults and seismicity in the Appalachian Basin of New York State: Tectnophysics, v. 353 , p. $75-113$.

Olcott, P.G., 1995, Ground water atlas of the United StatesConnecticut, Maine, Massachusetts, New Hampshire, New York, Rhode Island, Vermont: U.S. Geological Survey Hydrologic Atlas 730-M.

Reis, K.G., Guthrie, J.D., Rea, A.H., Steeves, P.A., and Stewart, D.W., 2008, Streamstats: a water resources web application: U.S. Geological Survey Fact Sheet 2008-3067, $6 \mathrm{p}$. 
Richards, P.L., Libby, Jill, Kuhl, Alex, Daniluk, T.L., and Lyzwa, Mike, 2010, Prediction of areas sensitive to fertilizer application in thinly-soiled karst-final report: Brockport, NY, State University of New York at Brockport, 27 p.

Rickard, L.V., 1973, Stratigraphy and the structure of the subsurface Cambrian and carbonates of New York: New York State Museum Map and Chart Series, no. 12, 55 p., $12 \mathrm{pl}$.
Staubitz, W.W., and Miller, T.S., 1987, Geology and hydrology of the Onondaga aquifer in eastern Erie County, New York, with emphasis on ground-water-level declines since 1982: U.S. Geological Survey Water-Resources Investigations Report 86-4317, 44 p.

Wulforst, J.P., Wertz, W.A., and Leonard, R.P., 1969, Soil Survey of Genesee County, New York: Soil Conservation Service, U.S. Department of Agriculture, 179 p. 


\section{Appendix 1}

Ten quadrangle plates of Genesee County, which overlie the carbonate-rock study area:

Northern Tier Quadrangles:

Akron (Plate1, map 1) http://pubs.usgs.gov/sim/3132/Plate1_map1_Akron.pdf

Akron (Plate1, map 2) http://pubs.usgs.gov/sim/3132/Plate1_map2_Akron.pdf

Oakfield (Plate 2, map 1) http://pubs.usgs.gov/sim/3132/Plate2_map1_Oakfield.pdf

Oakfield (Plate 2, map 2) http://pubs.usgs.gov/sim/3132/Plate2_map2_Oakfield.pdf

Batavia North (Plate 3, map 1) http://pubs.usgs.gov/sim/3132/Plate3_map1_BataviaNorth.pdf

Batavia North (Plate 3, map 2) http://pubs.usgs.gov/sim/3132/Plate3_map2_BataviaNorth.pdf

Byron (Plate 4, map 1) http://pubs.usgs.gov/sim/3132/Plate4_map1_Byron.pdf

Byron (Plate 4, map 2) http://pubs.usgs.gov/sim/3132/Plate4vmap2_Byron.pdf

Churchville (Plate 5, map 1) http://pubs.usgs.gov/sim/3132/Plate5_map1_Churchville.pdf

Churchville (Plate 5, map 2) http://pubs.usgs.gov/sim/3132/Plate5_map2_Churchville.pdf

Southern Tier Quadrangles:

Corfu (Plate 6, map 1) http://pubs.usgs.gov/sim/3132/Plate6_map1_Corfu.pdf

Corfu (Plate 6, map 2) http://pubs.usgs.gov/sim/3132/Plate6_map2_Corfu.pdf

Alexander (Plate 7, map 1) http://pubs.usgs.gov/sim/3132/Plate7_map1_Alexander.pdf

Alexander (Plate 7, map 2) http://pubs.usgs.gov/sim/3132/Plate7_map2_Alexander.pdf

Batavia South (Plate 8, map 1) http://pubs.usgs.gov/sim/3132/Plate8_map1_BataviaSouth.pdf

Batavia South (Plate 8, map 2) http://pubs.usgs.gov/sim/3132/Plate8_map2_BataviaSouth.pdf

Stafford (Plate 9, map 1) http://pubs.usgs.gov/sim/3132/Plate9_map1_Stafford.pdf

Stafford (Plate 9, map 2) http://pubs.usgs.gov/sim/3132/Plate9_map2_Stafford.pdf

LeRoy (Plate 10, map 1) http://pubs.usgs.gov/sim/3132/Plate10_map1_LeRoy.pdf

LeRoy (Plate 10, map 2) http://pubs.usgs.gov/sim/3132/Plate10_map2_LeRoy.pdf

Quadrangle Plate 1-10 Map 1-Surficial bedrock units, location of agricultural land-use areas and thin soils, karst features and associated bounding areas or watersheds, and location of documented contaminant spills.

Quadrangle Plate 1-10 Map 2-Location of wells used in the study, bedrock surface contours, anthropogenic features, agricultural land-use areas and thin soils. 
Prepared by the Pembroke Publishing Service Center

For additional information write to:

New York Water Science Center

U.S. Geological Survey

30 Brown Rd.

Ithaca, NY 14850

Information requests:

(518) 285-5602

or visit our Web site at: http://ny.water.usgs.gov 


\section{总}

밈
을

言

흠

$>$

旡

욱

กิ

을

중

훟

욤

흘

产

옹

言

三.

串

串

ஓ

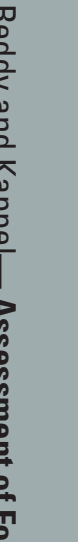

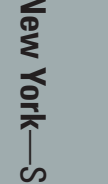

言:

三

怘

훙. 